\title{
Współpraca logopedy z laryngologiem i foniatrą w procesie rehabilitacji zaburzeń głosu i mowy
}

\section{Cooperation Among Speech Therapists, Laryngologists And Phoniatricians In The Rehabilitation Of Speech And Voice Disorders}

Słowa kluczowe: logopedia, współpraca specjalistów, zadania logopedy

Keywords: speech therapy, cooperation of specialists, the task of a speech therapist

\section{Wprowadzenie}

Obok funkcjonujących w społeczeńst wie potocznych opinii, że „logopeda jest specjalistą zajmującym się tylko usuwaniem zaburzeń mowy i wymowy u dzieci (częściej) i dorosłych (rzadziej)" [Kamińska, Siebert, 2012, s. 236], w ostatnich latach ugruntowało się stanowisko, że logopedia jest oparta między innymi na naukowych podstawach medycznych. Takie stanowisko zajmuje na przykład Stanisław Grabias, zwracając uwagę na fakt, iż z tej perspektywy dla logopedy istotne stają się [Grabias, 2010/2011, s. 18]:

1) ocena i objaśnianie relacji zachodzących między stanami języka i zachowaniami językowymi a przebiegiem centralnych i obwodowych procesów warunkujących język i zachowania językowe;

2) budowanie teorii i praktyki postępowania prowadzącego do zmiany stanów niepożądanych, ewentualnie do podtrzymywania lub doskonalenia stanów zgodnych z biologiczną normą.

Również autorzy artykułów zamieszczonych w tomie Biomedyczne podstawy logopedii pod redakcją Stanisława Milewskiego, Jerzego Kuczkowskiego, Katarzyny Kaczorowskiej-Bray [2014] podkreślają biomedyczne uwarunkowania rozwoju oraz zaburzeń mowy i języka.

* Zakład Dialektologii Polskiej i Logopedii, Instytut Filologii Polskiej i Logopedii, Wydział Filologiczny Uniwersytetu Łódzkiego, ul. Pomorska 171/173, 90-236 Łódź, e-mail: renata.marciniak@uni. lodz.pl. 
Powyższe założenie, wiążące logopedię z naukami medycznymi, nie stanowi novum - o związkach logopedii z naukami medycznymi mówi się od lat dwudziestych XX wieku. Władysław Ołtuszewski jako jeden z pierwszych wykazał ścisłą zależność między fonacją a artykulacją oraz związek tych dwu czynności ze słuchem zarówno w stanach fizjologicznych, jak i patologicznych. W historii medycyny odegrał ważną rolę, wykazując przyczyny, metody badania klinicznego w przypadkach uszkodzenia obwodowego i centralnego narządów mowy, głosu i słuchu. Był autorem kilkudziesięciu prac z dziedziny fizjologii i patologii mowy, w języku polskim, niemieckim, rosyjskim i francuskim. Przykładem związku logopedii z medycyną może być też fakt, że w czasie otwarcia I Kongresu Międzynarodowego Towarzystwa Logopedów i Foniatrów w Wiedniu w lipcu 1924 roku w swoim referacie współorganizator tego kongresu Emil Fröschels stwierdził, iż „Logopädie ist eine medizinische Wissenschaft” [„Logopedia/terapia mowy jest nauką medyczną” - tłum. R.M.-F.] i podkreślił jednocześnie, że wymaga ona doskonałej znajomości laryngologii, neurologii, psychiatrii i pediatrii [za: Obrębowski, Pruszewicz, 1999, s. 126].

Również Leon Kaczmarek, pisząco powiązaniach logopedii z innymi dyscyplinami, wymienia z zakresu medycyny foniatrię, audiologię, anatomię oraz fizjologię, patologięi rozwój narządów mowy, neurologię, psychiatrię, pediatrię, biologię dziecka [Kaczmarek, 1991].

$\mathrm{W}$ ostatnich kilkunastu latach, w związku z olbrzymimi postępami w medycynie i tworzeniem się wielospecjalistycznych zespołów, zacieśnia się związek logopedii z medycyną.

Celem artykułu jest omówienie wybranych aspektów współpracy logopedy z laryngologiem (przede wszystkim specjalizującym się w onkologii laryngologicznej) i foniatrą. Zaprezentuję wybrane aspekty tej współpracy, między innymi zadania logopedy - członka interdyscyplinarnego zespołu specjalistów - w procesie terapii:

1) osób z chorobami nowotworowymi w obrębie jamy ustnej, jamy nosowej, krtani i gardła,

2) osób z zawodowymi dysfoniami.

\section{Współpraca logopedy z laryngologiem ${ }^{1} \mathrm{w}$ rehabilitacji zaburzeń głosu i mowy}

Obszarem zainteresowań zawodowych laryngologa są choroby uszu, zatok, nosa, kości skroniowej, tchawicy, krtani, oskrzeli, przełyku, gardła oraz narządy zmysłów: słuch, węch, smak, równowagi. Wśród licznych uprawnień laryngologa w zakresie diagnozy, wykonywania zabiegów chirurgicznych i rehabilitacji wymienia się między innymi leczenie nowotworów okolic głowy i szyi.

1 Wyodrębnienie w artykule kwestii współpracy logopedy z laryngologiem i foniatrą ma tylko charakter porządkujący, niekiedy trudno bowiem oddzielić kompetencje tych lekarzy. 
W literaturze logopedycznej [por. Sinkiewicz, 1999; 2009] najczęściej opisywany jest nowotwór krtani, powodujący zaburzenia głosu i mowy. Rocznie na świecie notuje się około 100 tysięcy przypadków raka krtani, z czego kilkadziesiąt tysięcy poddawanych jest laryngektomii całkowitej. Polska należy do krajów o dużej zapadalności na tę chorobę [Hamerlińska-Latecka, 2012, s. 60]. W ostatnich latach wzrasta liczba zachorowań u kobiet i liczba chorych w młodszym wieku.

Krtań jako część drogi oddechowej pełni funkcję: oddechową, fonacyjną, obronną, odruchową, pola recepcyjnego dla wyższych odruchów, wreszcie ułatwia powrót krwi żylnej do serca. Tu krzyżuje się droga pokarmowa (wejście do przełyku) z drogą oddechową. Praca krtani jako zwieracza ma istotne znaczenie w mechanizmie parcia podczas oddawania stolca i moczu oraz w trakcie porodu.

Usunięcie krtani skraca drogę oddechową - zaczyna się ona nie od nosa, ale od stomy wszytej do skóry, stąd powietrze dochodzące do płuc jest niedogrzane, o złej wilgotności i zanieczyszczone. Po operacji krtani osłabia się lub zmienia poczucie węchu, smaku, połykania, parcia oraz odruchy kaszlu i kichania.

Czynniki predysponujące do nowotworu krtani to [por. Hamerlińska-Latecka, 2012, s. 61]:

1) długotrwale działanie jako kancerogenu dymu tytoniowego;

2) nadużywanie alkoholu;

3) działanie toksyn chemicznych w miejscach pracy;

4) dieta uboga w witaminy A i C. Wśród nowotworów występujących w narządach artykulacyjnych odpowiedzialnych za powstawanie mowy wyróżnić można także nowotwory jamy ustnej, guzy zębopochodne i torbiele nabłonkowe oraz nowotwory szczęk i żuchwy (por. tabela 1).

Wymienione w tabeli 1 choroby nowotworowe i ich lokalizacja wskazują na to, że w proces leczenia chorego musi zaangażować się interdyscyplinarny zespół specjalistów, między innymi lekarz, pielęgniarka, fizjoterapeuta, psycholog i bezsprzecznie logopeda (onkologopeda). Onkologopeda ${ }^{2}$ to specjalista zajmujący się badaniem, diagnozą i terapią logopedyczną osób (dzieci, młodzieży i dorosłych) z objawami zaburzeń mowy (w obrębie głowy, twarzy, jamy ustnej, szczęk, szyi i krtani), zaburzeń komunikacji, dysfagią - wywołanymi chorobą nowotworową i/lub będącymi konsekwencją jej leczenia [por. Hamerlińska-Latecka, 2012, s. 64]. Pierwotną przyczyną zaburzeń mowy jest choroba nowotworowa, wtórną - konsekwencje jej leczenia [Hamerlińska-Latecka, 2012, s. 64]. U laryngektomowanych poddanych wtórnej radioterapii mogą bowiem występować reakcje bólowe z zaburzeniami ruchów języka, żucia i połykania na skutek suchości i pieczenia w jamie ustnej i gardle [Studzińska i wsp., 2012, s. 125].

2 Pomysłodawczynią pojęć onkologopeda, onkologopedia i autorką nowatorskich prac z tej dziedziny jest dr Agnieszka Hamerlińska z Uniwersytetu Mikołaja Kopernika w Toruniu. 
Tabela 1. Typy, przyczyny i objawy nowotworów narządów artykulacyjnych

\begin{tabular}{|c|c|c|c|}
\hline $\begin{array}{l}\text { Typy no- } \\
\text { wotworów } \\
\text { narządów } \\
\text { artykulacyj- } \\
\text { nych }\end{array}$ & $\begin{array}{l}\text { Nowotwory jamy ustnej } \\
\text { 1) (wszystkie częstsze u mężczyzn niż } \\
\text { u kobiet), } \\
\text { 2) rak wargi, } \\
\text { 3) rak ustnej części gardła, } \\
\text { 4) rak języka, } \\
\text { 5) rak dna jamy ustnej, } \\
\text { 6) rak błony śluzowej policzka, } \\
\text { 7) złośliwe nowotwory ślinianek } \\
\text { - predysponowane są szczególnie } \\
\text { ślinianki przyuszne, podżuchwowe, } \\
\text { podjęzykowe. }\end{array}$ & $\begin{array}{l}\text { Guzy zębopochodne } \\
\text { i torbiele } \\
\text { nabłonkowe. }\end{array}$ & $\begin{array}{l}\text { Nowotwory szczęk } \\
\text { i żuchwy. }\end{array}$ \\
\hline $\begin{array}{l}\text { Przyczyny } \\
\text { nowotworu }\end{array}$ & $\begin{array}{l}\text { 1) nikotynizm, } \\
\text { 2) alkoholizm, } \\
\text { 3) zakażenie wirusem HPV (wczesny } \\
\text { wiek inicjacji seksualnej, coraz częś- } \\
\text { ciej uprawiany seks oralny z różnymi } \\
\text { partnerami, większa liczba partne- } \\
\text { rów seksualnych), } \\
\text { 4) zła higiena jamy ustnej, } \\
\text { 5) mechaniczne drażnienie (np. źle } \\
\text { dobrana proteza zębowa). }\end{array}$ & $\begin{array}{l}\text { 1) zakażenie wiru- } \\
\text { sem brodawczaka } \\
\text { ludzkiego HPV, } \\
\text { 2) mutacje genów, } \\
\text { np. AMBN. }\end{array}$ & $\begin{array}{l}\text { 1) defekty ge- } \\
\text { netyczne, } \\
\text { 2) urazy, } \\
\text { 3) zakażenia, pro- } \\
\text { cesy zapalne } \\
\text { (np. przewlekłe } \\
\text { zapalenie ozęb- } \\
\text { nej, zapalenie } \\
\text { szpiku i kości } \\
\text { szczęki). }\end{array}$ \\
\hline $\begin{array}{l}\text { Objawy } \\
\text { nowotworu }\end{array}$ & $\begin{array}{l}\text { 1) utrata czucia lub odrętwienie w ja- } \\
\text { mie ustnej, } \\
\text { 2) bolesne zmiany w okolicy warg, } \\
\text { policzków czy dziąseł, które się nie } \\
\text { goją i łatwo krwawią (np. owrzodze- } \\
\text { nia niegojące się przez 2-4 tyg.), } \\
\text { 3) guzek lub zgrubienie występujące } \\
\text { po wewnętrznej części policzka, } \\
\text { 4) białe lub czerwone plamki występują- } \\
\text { ce w obrębie jamy ustnej, } \\
\text { 5) trudności z żuciem oraz przełyka- } \\
\text { niem pokarmów, } \\
\text { 6) ból promieniujący do ucha (otalgia) } \\
\text { 7) obrzęk żuchwy lub szczęki wpływa- } \\
\text { jący na złe dopasowanie protezy, } \\
\text { 8) krwawienia z jamy ustnej, } \\
\text { 9) asymetria migdałków podnie- } \\
\text { biennych, } \\
\text { 10) szczękościsk, } \\
\text { 11) ślinotok, } \\
\text { 12) nieprzyjemny zapach z ust. }\end{array}$ & 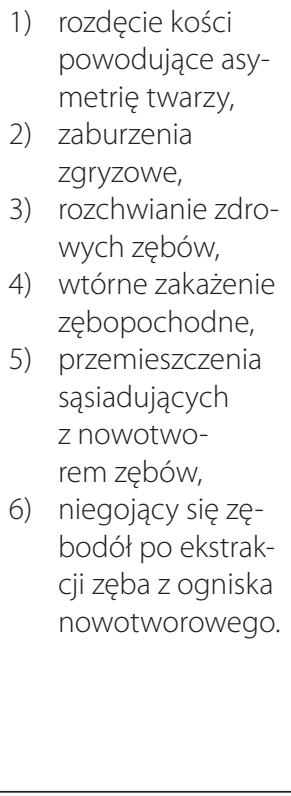 & 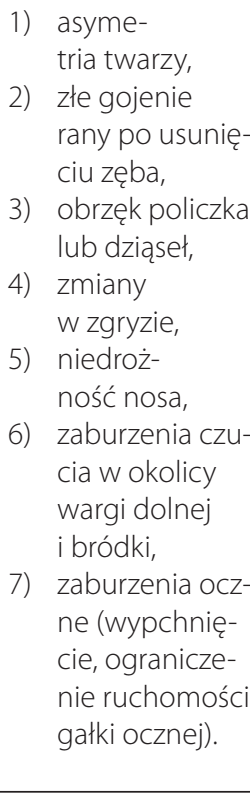 \\
\hline
\end{tabular}

Źródło: opracowanie własne na podstawie: Wójtowicz, Pabiszczak, 2002; Kaczmarzyk i wsp., 2009;

Hamerlińska-Latecka, 2012. 
Tabela 2. Mowa przełykowa a mowa gardłowa i przetokowa

\begin{tabular}{|c|c|}
\hline Mowa przełykowa & Mowa gardłowa \\
\hline $\begin{array}{l}\text { 1. Rolę generatora dźwięku przejmują fałdy } \\
\text { śluzówki przełyku. } \\
\text { 2. Pseudogłośnia zlokalizowana jest w przełyku. } \\
\text { 3. Głos ma nienaturalnie niskie brzmienie, jest } \\
\text { stosunkowo niski i ma małą rozpiętość. } \\
\text { 4. Pozwala na przekazywanie treści } \\
\text { semantycznych, ale ogranicza przekazywanie } \\
\text { treści emocjonalnych. } \\
\text { 5. Czynność mówienia jest męcząca, zmusza } \\
\text { to chorego do częstych przerw w toku } \\
\text { wypowiedzi. } \\
\text { 6. Rehabilitacja trwa długo, jej efektywność } \\
\text { jest stosunkowo niewysoka (od } 12 \text { do 24\% } \\
\text { rehabilitowanych pacjentów opanowuje } \\
\text { ją w stopniu bardzo dobrym, ale aż 33-54\% } \\
\text { nie jest zdolna tego dokonać nawet } \\
\text { w stopniu minimalnym). }\end{array}$ & 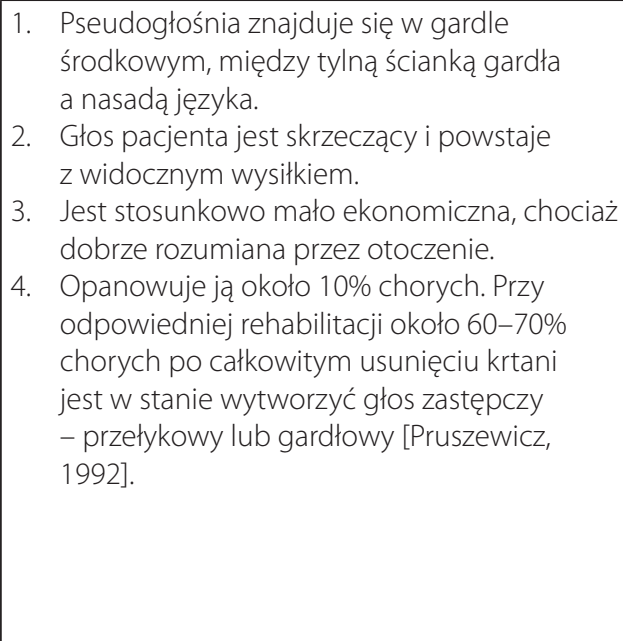 \\
\hline \multicolumn{2}{|c|}{ Mowa przetokowa (przetokowo-przełykowa i przetokowo-gardłowa) } \\
\hline \multicolumn{2}{|c|}{$\begin{array}{l}\text { 1. Warunki anatomiczne uzyskuje się dzięki zabiegom chirurgicznym (miotomia), które polegają na } \\
\text { wytworzeniu przetok głosowych i zastosowaniu odpowiednich protez. } \\
\text { 2. Mowa przetokowa ma przyjemniejszą barwę dźwięku, dłuższy czas fonacji, lepsze zaznaczenie } \\
\text { melodii, większą płynność wypowiedzi. } \\
\text { 3. Czas rehabilitacji niezbędny do jej wytworzenia jest stosunkowo krótki; oprócz tego, że } \\
\text { rehabilitowany „odzyskiwałgłos", to jeszcze dodatkowo poprawiało się jego psychiczne } \\
\text { funkcjonowanie, co potwierdzają badania Antoniego Pruszewicza, por. „Postępy w rehabilitacji } \\
\text { dźwięcznej werbalnej komunikatywności (postępy w rehabilitacji głosu przełykowego) po } \\
\text { laryngektomii prowadziły do ustępowania objawów depresyjnych” [za: Studzińska i in., 2012, s. 126]. }\end{array}$} \\
\hline
\end{tabular}

Źródło: za: Jastrzębowska, Pelc-Pękala, 2003.

Zadania (onko)logopedy jako członka zespołu interdyscyplinarnego to ${ }^{3}$ :

1) badanie zaburzeń mowy, zaburzeń komunikacji, dysfagii o etiologii nowotworowej;

2) diagnoza zaburzeń mowy, zaburzeń komunikacji, dysfagii o podłożu onkologicznym;

3) terapia logopedyczna osób z chorobą onkologiczną w obrębie głowy, jamy ustnej i szyi, w tym:

a) tworzenie programów terapii zaburzeń mowy pochodzenia nowotworowego;

b) wczesne włączenie ćwiczeń oddechowych przede wszystkim u osób po laryngektomii całkowitej;

c) restytucja mowy (ponowne uczenie mowy) w możliwym do osiągnięcia zakresie - przede wszystkim nauka mowy przełykowej lub gardłowej w przypadku laryngektomii całkowitej (por. tabela 2), by uniknąć nawyku posługiwania się pseudoszeptem;

3 Zadania podaję za Hamerlińska-Latecka, 2012, s. 64-65; 2015, s. 69. 
4) polepsza się wyrazistość mówienia, usprawnianie artykulacji na przykład w przypadku nowotworów jamy ustnej czy nosowej;

5) rozwija się komunikacja alternatywna i wspomagająca dla dzieci i dorosłych;

6) prowadzenie terapii połykania w sytuacji dysfunkcji - ponowna nauka połykania przez ćwiczenia narządów ze sfery orofacjalnej, ale również usprawnianie gryzienia, żucia czy połykania na przykład w przypadku nowotworów jamy ustnej;

7) współpraca ze specjalistami prowadzącymi proces leczenia osoby z chorobą nowotworową;

8) opracowywanie wskazówek do komunikacji interpersonalnej w relacji logopeda-pacjent i jego rodzina [por. Hamerlińska-Latecka, 2012, s. 64-65; 2015, s. 69]; ważne są - jak podkreślają Katarzyna Studzińska, Andrzej Obrębowski i inni - „znajomość i przestrzeganie zasad dobrej komunikacji przez zespół osób zajmujących się nimi: laryngologa, foniatry, logopedy, psychologa, pielęgniarki i fizjoterapeuty. Celem właściwego porozumiewania się z chorym i jego rodziną jest wyzwolenie w nim poprzez nawiązanie dobrego kontaktu motywacji do leczenia i współpracy w trakcie rehabilitacji” [Studzińska i wsp., 2012, s. 126].

\section{Współpraca logopedy z foniatrą w rehabilitacji zaburzeń głosu i mowy}

Foniatra to specjalista zajmujący się między innymi diagnozowaniem i leczeniem schorzeń struktur tworzących narząd głosotwórczy człowieka, a zlokalizowanych w jamie ustnej, gardle i krtani. Wraz z logopedą (terapeutą głosu, trenerem emisji głosu) uczestniczy w procesie leczenia i rehabilitacji zawodowych zaburzeń głosu, które cechują między innymi następujące objawy [Śliwińska-Kowalska, Niebudek-Bogusz, 2009, s. 28]:

1) nawykowe chrząkanie,

2) uczucie przeszkody w gardle,

3) parestezje gardła i krtani,

4) zmatowienie głosu,

5) zawężenie skali głosu,

6) skrócenie czasu fonacji,

7) okresowe zaniki głosu,

8) utrwalona chrypka,

9) bezgłos (afonia).

Należy dodać, że w Polsce od kilkunastu lat pierwsze miejsce na liście najczęściej występujących chorób zawodowych zajmują schorzenia narządu głosu [Gębska, Wojciechowska, Żyżniewska-Banaszak, 2011, s. 78].

Czynniki ryzyka predysponujące do zawodowo uwarunkowanych zaburzeń głosu to [Gębska, Wojciechowska, Żyżniewska-Banaszak, 2011, s. 79]: 
1) czynniki wewnętrzne:

a) zmiany w ośrodkowym i autonomicznym układzie nerwowym;

b) cechy konstytucjonalne (typ budowy, stabilność układu sercowo-naczyniowego, pobudliwość neurowegetatywna, struktura osobowości, typ błony śluzowej, czynność krtani i nasady);

c) wiek;

d) płeć;

e) stan słuchu (wydolność tego narządu i słuch muzyczny);

f) zakres wydolności narządu głosu, artykulacja, wydolność oddechowa;

g) stan endokrynologiczny (np. niedoczynność tarczycy, androgenizacja, spadek poziomu hormonów u kobiety);

h) konfliktowość, wzmożona pobudliwość nerwowa, umiejętność nawiązywania kontaktów;

i) podatność na schorzenia górnych dróg oddechowych, skłonności alergiczne;

2) czynniki zewnętrzne:

a) staż pracy (liczba godzin w ciągu dnia, liczba lat pracy);

b) przygotowanie głosu do pracy pedagogicznej (niedostatki edukacji głosowej i brak odpowiedniego treningu w aktywności głosowej);

c) warunki pracy (złe warunki akustyczne, przedłużony czas pracy, nierównomierny rozkład zajęć, brak odpowiednich mikrofonów, wilgotność, temperatura, zapylenie powietrza);

d) hałas;

e) stosunki międzyludzkie w zakładzie pracy (stres);

f) poważne schorzenia ogólne (np. refluks żołądkowo-przełykowy);

g) używki (palenie papierosów, spożywanie alkoholu).

W ogólnoświatowych trendach dotyczących postępowania w dysfoniach zawodowych dominuje podejście holistyczne, celem kompleksowego leczenia zawodowych zaburzeń głosu jest bowiem przywrócenie takiego stanu narządu głosu, który spełniałby zarówno socjalne, emocjonalne, jak i zawodowe potrzeby pacjenta [Śliwińska-Kowalska, Niebudek-Bogusz, 2009, s. 35].

Wśród metod terapii zaburzeń głosu (np. rehabilitacja głosu, mikrochirurgia, farmakoterapia, psychoterapia, fizjoterapia, leczenie balneologiczne) najważniejsza jest rehabilitacja głosu, która ma za zadanie przywrócić prawidłową funkcję głosową krtani przez korektę emisji głosu, usprawnienie narządu głosu i jego powrót do optymalnego działania. Rehabilitacja głosu zawodowego jest również jednym z najważniejszych elementów postępowania profilaktycznego [Śliwińska-Kowalska, Niebudek-Bogusz, 2009, s. 36]. W skład profilaktyki i rehabilitacji zaburzeń głosu wchodzą działania pośrednie dotyczące przestrzegania higieny głosu i zdrowego stylu życia oraz poprawy warunków środowiska pracy, a także bezpośrednie - obejmujące szkolenie technik prawidłowej emisji głosu [Niebudek-Bogusz, Woźnicka, 2011, s. 157]. 
W rehabilitacji głosu bardzo ważna jest współpraca logopedy i foniatry. Jak piszą Andrzej Obrębowski i Antoni Pruszewicz:

Lekarz foniatra ściśle współpracuje z logopedą i psychologiem klinicznym. Jest to podstawowy zespół specjalistyczny niezbędny do zapewnienia właściwej opieki w zaburzeniach procesu komunikatywnego [Obrębowski, Pruszewicz, 1999, s. 124-125].

Zwracają też uwagę na fakt, że:

Foniatra widzi w logopedzie blisko współpracującego partnera, który nie tylko realizuje program rehabilitacji w odniesieniu do konkretnego chorego, ale pomaga w ustaleniu ostatecznego rozpoznania oraz w prognozowaniu [Obrębowski, Pruszewicz, 1999, s. 126-127].

Jednocześnie podkreślają, że bliska współpraca i wzajemne zrozumienie tych specjalistów pozwoli na postawienie na najwyższym jakościowo poziomie diagnostyki i leczenia zaburzeń głosu [Obrębowski, Pruszewicz, 1999, s. 127]. Podobnie wypowiadają się naukowcy warszawscy:

Ścisła współpraca [logopedy] z lekarzem foniatrą pomaga w dokładnym ukierunkowaniu rehabilitacji oraz okresowej ocenie jej efektów, co pozwala na szybsze osiągnięcie celu [Sielska-Badurek i wsp., 2012, s. 88].

Zadania logopedy (terapeuty głosu, trenera emisji głosu) jako członka zespołu interdyscyplinarnego to:

1) uczestniczenie w rehabilitacji pacjentów, mającej na celu eliminowanie zaburzeń hiperfunkcyjnych, które doprowadzają do powstania guzków głosowych;

2) prowadzenie ćwiczeń z emisji głosu; zdarza się, że zmiany typu guzki głosowe, małe przerosty polipowate fałdów głosowych lub owrzodzenia kontaktowe ustępują po rehabilitacji głosu, bez konieczności operacji;

3) prowadzenie działań edukacyjnych skierowanych na profilaktykę w zakresie higieny głosu; w profilaktyce zaburzeń głosu zwraca się uwagę między innymi na wyeliminowanie nadużyć głosowych (mówienie przy znacznym hałasie, kaszel i nadmierne chrząkanie, palenie papierosów, zbyt głośne mówienie i śpiewanie przy infekcjach górnych dróg oddechowych lub w czasie nasilenie objawów alergicznych), a także wyeliminowanie błędów wynikających z niewłaściwego użycia głosu (mówienie przez dłuższy czas z twardym nastawieniem głosowym, zwiększenie natężenia przez „wyciskanie” głosu na poziomie krtani, mówienie z nadmiernym natężeniem, dłuższe mówienie z niewłaściwą wysokością głosu, najczęściej podwyższoną, mówienie przez długi czas) [Gębska, Wojciechowska, Żyżniewska-Banaszak, 2011, s. 81]; 
4) podejmowanie działań rehabilitacyjnych, których celem jest likwidacja nieprawidłowych nawyków tworzenia głosu, prowadzenie ćwiczeń (oddechowych, fonacyjnych, relaksacyjnych, artykulacyjnych) dobranych indywidualnie do potrzeb pacjenta, uwzględniających jego wiek, płeć oraz ogólną kondycję [Niebudek-Bogusz, Woźnicka, 2011, s. 159];

5) instruowanie pacjenta o sposobie wykonywania ćwiczeń oraz zwrócenie uwagi na najczęściej popełniane błędy; spotkania pacjenta z terapeutą służą również sprawdzeniu poprawności wykonywania ćwiczeń oraz korekcji ewentualnie popełnianych błędów; logopeda powinien przygotować dla pacjenta zestaw materiałów zawierający opis ćwiczeń do samodzielnej pracy w domu [por. Niebudek-Bogusz, Woźnicka, 2011, s. 159];

6) wypracowanie u pacjenta sprawnego i wydajnego głosu; sprawny głos to głos mogący sprostać wymogom frazy, tj. długości, skali, dynamice i tempu, wydajny głos to głos, w którym powietrze zostaje całkowicie zużyte na płynącą wąskim strumieniem falę dźwiękową, przy zawsze zachowanej pewnej jego rezerwie oddechowej [Niebudek-Bogusz, Woźnicka, 2011, s. 161];

7) zapoznawanie się $\mathrm{z}$ wynikami badań specjalistycznych przeprowadzanych na różnych etapach pracy z pacjentem i dostosowywanie do tych wyników programu terapii przez jego weryfikację i modyfikację;

8) pomoc w utrzymaniu przez pacjenta właściwej postawy, prawidłowych nawyków czy dokonywanej systematycznie wieloaspektowej, krytycznej samooceny [Kaźmierczak, 2016, s. 94];

9) wpływanie na środowisko, w którym pacjent z zaburzeniami głosy funkcjonuje na co dzień, tj. edukacja członków rodziny, współpracowników itp. [Kaźmierczak, 2016, s. 95].

Świadoma systematyczna praca nad elementami treningu głosowego przyczynia się do osiągnięcia prawidłowej koordynacji oddechowo-fonacyjno-artykulacyjnej, zmniejszenia napięcia fizycznego i psychicznego, a tym samym do umiejętności wytwarzania głosu swobodnego i naturalnego [Niebudek-Bogusz, Woźnicka, 2011, s. 162].

\section{Podsumowanie}

Działania logopedy powinny mieć charakter polimodalny, wieloprofilowy, interdyscyplinarny, tj. powinny być ukierunkowane na wszystkie sfery rozwoju człowieka, z którymi mowa ma istotne powiązania. Ważna jest również umiejętność współpracy logopedy $z$ innymi specjalistami, między innymi z laryngologiem czy foniatrą. Zadaniem logopedy w zespole wielospecjalistycznym w przypadku chorób onkologicznych czy zaburzeń głosu jest przede wszystkim diagnoza i terapia logopedyczna zaburzeń mowy, komunikacji i dysfagii u osób z chorobą nowotworową w obrębie 
głowy, jamy ustnej i szyi oraz diagnoza i rehabilitacja pacjentów z zaburzeniami głosu. Działania logopedy powinny obejmować również kwestie edukacyjne, skierowane na profilaktykę w zakresie higieny głosu. Tam, gdzie współpraca między specjalistami jest życzliwa, można liczyć na pozytywne rezultaty terapeutyczne. Kluczowym elementem pracy zespołu specjalistów jest przede wszystkim wymiana informacji, szacunek do wiedzy innych członków zespołu i wspólne podejmowanie decyzji służących dobru pacjenta [por. Sielska-Badurek i wsp., 2012, s. 88].

\section{Literatura}

Gębska Magdalena, Wojciechowska Alina, Żyżniewska-Banaszak Ewelina, 2011, Zasady i metody rehabilitacji chorych z zawodowymi zaburzeniami głosu, „Annales Academiae Medicae Stetinnesis. Roczniki Pomorskiej Akademii Medycznej w Szczecinie”, nr 57(2), s. 78-84.

Grabias Stanisław, 2010/2011, Logopedia - nauka o biologicznych uwarunkowaniach języka i zachowaniach jezykowych, „Logopedia”, t. 39-40, s. 9-34.

Hamerlińska-Latecka Agnieszka, 2012, Onkologopedia - o potrzebie utworzenia nowej specjalności w logopedii, [w:] J.J. Błeszyński (red.), Medycyna w logopedii. Terapia - wspomaganie - wsparcie. Trzy drogi - jeden cel, Toruń: Wydawnictwo Harmonia, s. 57-66.

Hamerlińska-Latecka Agnieszka, 2015, Onkologopedia. Logopedia wobec chorób nowotworowych, Bydgoszcz: Wydawnictwo Uniwersytetu Kazimierza Wielkiego w Bydgoszczy.

Jastrzębowska Grażyna, Pelc-Pękala Olga, 2003, Mowa laryngektomowanych, [w:] T. Gałkowski, G. Jastrzębowska (red.), Logopedia. Pytania i odpowiedzi. Podręcznik akademicki, t. 2: Zaburzenia komunikacji językowej u dzieci i osób dorostych, wyd. II, Opole: Wydawnictwo Uniwersytetu Opolskiego, s. 796-803.

Kaczmarek Leon, 1991, O polskiej logopedii, [w:] H. Borowiec (red.), Przedmiot logopedii, Lublin: Wydawnictwo Uniwersytetu Marii Curie-Skłodowskiej, s. 26-41.

Kaczmarzyk Tomasz, Stypułkowska Jadwiga, Tomaszewska Romana, Czopek Jacek, 2009, Nowotwory zębopochodne i guzy nowotworopodobne kości szczękowych. Podręcznik dla studentów i lekarzy, Warszawa: Wydawnictwo Kwintesencja.

Kamińska Barbara, Siebert Beata, 2012, Podstawy rozwoju mowy u dzieci, „Forum Medycyny Rodzinnej" t. 6, nr 5, s. 236-243.

Kaźmierczak Monika, 2016, Świadomość celu w pracy logopedy i pacjenta z zaburzeniami głosu, „Prace Naukowe Akademii im. Jana Długosza w Częstochowie. Pedagogika” t. XXV, s. 87-97.

Milewski Stanisław, Kuczkowski Jerzy, Kaczorowska-Bray Katarzyna (red.), 2014, Biomedyczne podstawy logopedii, Gdańsk: Wydawnictwo Harmonia.

Niebudek-Bogusz Ewa, Woźnicka Ewelina, 2011, Profilaktyka chorób zawodowych narządu głosu, [w:] M. Śliwińska-Kowalska (red.), Zasady orzekania o predyspozycjach zawodowych do pracy w narażeniu na hałas i nadmierny wysiłek głosowy oraz diagnostyka i profilaktyka chorób narzadu stuchu i narządu głosu, Warszawa: Centrum Medyczne Kształcenia Podyplomowego, s. 157-163.

Obrębowski Andrzej, Pruszewicz Antoni, 1999, Wspótpraca foniatry i logopedy w diagnozowaniu i rehabilitacji zaburzeń procesu komunikatywnego, „Logopedia”, t. 26, s. 123-128.

Pruszewicz Antoni (red.), 1992, Foniatria kliniczna, Warszawa: Państwowy Zakład Wydawnictw Lekarskich. 
Sinkiewicz Anna, 1999, Rak krtani: poradnik dla pacjentów, logopedów i lekarzy, Bydgoszcz: Polskie Towarzystwo Laryngektomowanych, Polskie Towarzystwo Otolaryngologów - Chirurgów Głowy i Szyi.

Sinkiewicz Anna (red.), 2009, Pacjent po operacji krtani, Bydgoszcz: Bydgoskie Stowarzyszenie Laryngektomowanych.

Sielska-Badurek Ewelina, Kazanecka Ewa, Osuch-Wójcikiewicz Ewa, Domeracka-Kołodziej Anna, 2012, Rola foniatry w multidyscyplinarnej opiece nad wokalistami, „Otorynolaryngologia”, nr 11(3), s. 87-94.

Studzińska Katarzyna, Obrębowski Andrzej, Wiskirska-Woźnica Bożena, Obrębowska Zofia, 2012, Problemy psychologiczne w rehabilitacji chorych po operacjach całkowitego usunięcia krtani, „Polski Przegląd Otolaryngologiczny”, nr 2(1), s. 124-128.

Śliwińska-Kowalska Mariola, Niebudek-Bogusz Ewa (red.), 2009, Rehabilitacja zawodowych zaburzeń głosu. Poradnik dla nauczycieli, Łódź: Instytut Medycyny Pracy im. prof. J. Nofera w Łodzi.

Wójtowicz Jerzy G., Pabiszczak Maciej, 2002, Nowotwory złośliwe jamy ustnej i gardła, „Przewodnik Lekarza”, nr 9(45), s. 74-77 (dodatek specjalny „Otorynolaryngologii”).

\section{Streszczenie}

W związku z olbrzymimi postępami w medycynie i tworzeniem się wielospecjalistycznych zespołów w ostatnich kilkunastu latach zacieśnia się związek logopedii z medycyną. Celem artykułu jest omówienie wybranych aspektów współpracy logopedy z laryngologiem (przede wszystkim specjalizującym się w onkologii laryngologicznej) i foniatrą. Zaprezentowano wybrane aspekty tej współpracy, między innymi zadania logopedy - członka interdyscyplinarnego zespołu specjalistów - w procesie terapii osób z chorobami nowotworowymi w obrębie jamy ustnej, jamy nosowej, krtani i gardła oraz osób z zawodowymi dysfoniami.

\section{Summary}

Over the last few years considerable progress in medicine and the emergence of multispecialist teams have tightened the relationship between medicine and logopaedics. The aim of this paper is to discuss selected aspects of the cooperation among laryngologists (mainly those who specialise in oncological laryngology), and phoniatricians. I will present the selected aspects of this cooperation, among others aims of a speech therapist (a member of a multidisciplinary team of specialists) in therapies that can help people with cancer of the mouth, nasal cavity, larynx and throat; and people with professional dysphonia. 